\title{
Erratum: Theology of health of Quranic pesantren in the time of COVID-19
}

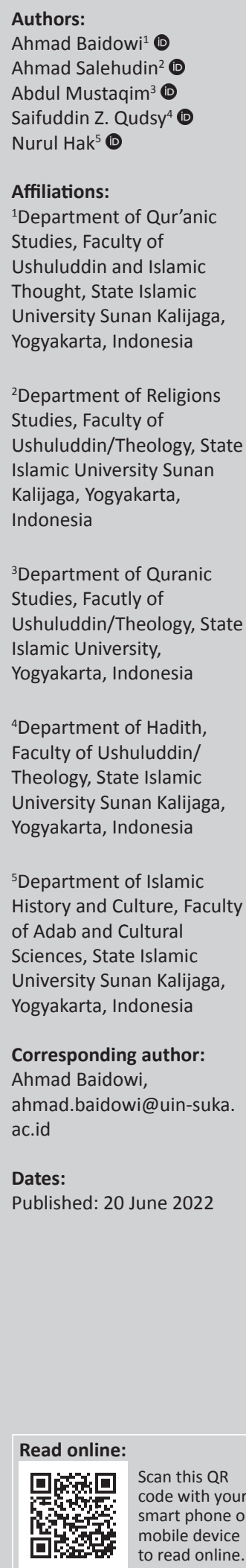

In the published article, Baidowi, A., Salehudin, A., Mustaqim, A., Qudsy, S.Z. \& Hak, N., 2021, 'Theology of health of Quranic pesantren in the time of COVID-19', HTS Teologiese Studies/ Theological Studies 77(4), a6452. https://doi.org/10.4102/hts.v77i4.6452, there was an error in the corresponding author's name and email address. The name and email address of Ahmad Baidowi, ahmad.baidowi@uin-suka.ac.id, was given incorrectly as Ahmad Salehudin, ahmad.salehudin@ uin-suka.ac.id. The correct name and email address should be Ahmad Baidowi, ahmad.baidowi@ uin-suka.ac.id.

The publisher apologises for this error. The correction does not change the significance of study's findings or overall interpretation of the its results or the scientific conclusions of the article in any way.

How to cite this correction: Baidowi, A., Salehudin, A., Mustaqim, A., Qudsy, S.Z. \& Hak, N., 2022, 'Erratum: Theology of health of Quranic pesantren in the time of COVID-19', HTS Teologiese Studies/Theological Studies 78(1), a7183. https://doi.org/10.4102/hts.v78i1.7183 Copyright: (C) 2022. The Authors. Licensee: AOSIS. This work is licensed under the Creative Commons Attribution License. Note: DOI of original article published: https://doi.org/10.4102/hts.v77i4.6452 


\section{Theology of health of Quranic pesantren in the time of COVID-19}

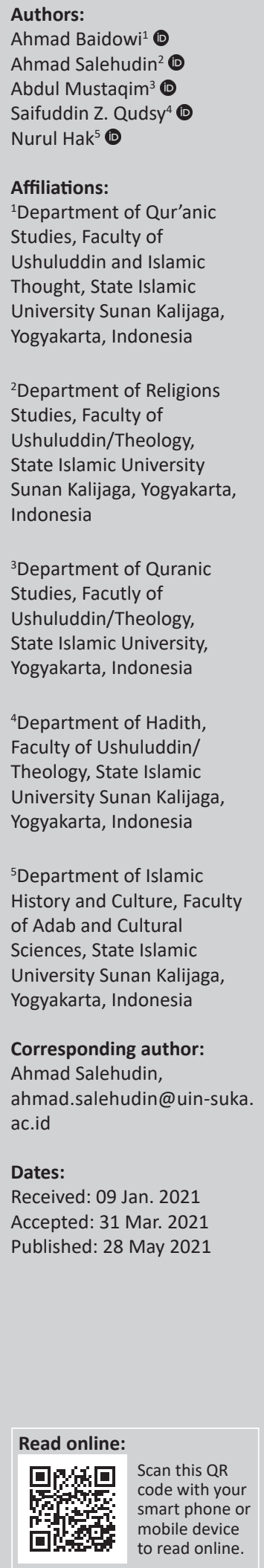

Applying the dormitory system for thousands of santri (student of Islamic boarding school in Indonesia), Quranic pesantren (Islamic boarding school) has been considered as one of the main culprits in the spread of the coronavirus disease 2019 (COVID-19). Such assumption is created solely from the applicable health protocols and protective measures to avoid COVID-19 transmission in pesantren. As a matter of fact, pesantrens are known to have applied a distinctive way of coping with COVID-19. This study aims to elucidate the theology of health of Quranic pesantren in the face of COVID-19. Research data were generated through observational method on three Quranic pesantrens in Yogyakarta, interviews with caregivers, the COVID-19 task force of the pesantren, santri and documentation related to the handling of COVID-19 in the three pesantrens. The results showed that the Quranic pesantren as a subculture has a distinctive way of dealing with COVID-19 pandemic by integrating modified health protocols in accordance with the actual conditions of the pesantren and by applying rituals of Islamic spirituality by reciting verses of the Qur'an, salawat (prayers for the Prophet), prayers and hizib (prayer for salvation and rejecting calamities). Three pesantrens chose these methods by drawing on the belief that COVID-19 is God's creature and, thus, it only works on God's orders and will stop if God wills. In line with this, this study suggests a method for handling COVID-19 by not only emphasising the health protocols and medical procedures but also taking into account the importance of local wisdom.

Contribution statement: This article contributes to the strategy of COVID-19 handling by combining the health protocols of COVID-19 and the applicable local wisdom, such as religious ritual as practiced by numerous pesantren in Indonesia.

Keywords: theology of health; Quranic pesantren; COVID-19; spiritual; local wisdom.

\section{Introduction}

Pesantren, which has long been known as the place to learn about Islam, tafaqquh fi al-din (gaining a deeper understanding on Islamic studies) (Dhofier 1984; Suryadi \& Mansur 2017; Wahid 2001), is now faced with the coronavirus disease 2019 (COVID-19) pandemic, which has caused unprecedented educational disruption. The rapid spread of COVID-19 has turned some pesantrens into a new cluster for the transmission of the virus. According to the Deputy Minister of Religion of the Republic of Indonesia, Zainut Tauhid, as of 15 November 2020, a total of 1700 santri were infected (https://www.ayotegal.com), whilst the number of kyai (male leaders of pesantren) and nyais (female leaders of pesantren) who passed away because of COVID-19 reached 100 (https://www.suaramerdeka.com). There has been a constantly alarming rise of the newly emerging pesantren clusters as the santri start to return to the pesantren. The latest data reveal 32 pesantrens in clusters, soaring from the number of 27 pesantrens in October 2020 (https://www.ayotegal.com). However, the escalation in COVID-19 cases at pesantren was not immediately responded by sending the santri home to their parents. Instead, the pesantrens continue to carry out learning activities by complying with the pesantren-style health protocols. Pesantren as a subculture (Wahid 2001), based on its theology and rationality, has an authentic survival strategy during the COVID-19 pandemic. The measurements taken by pesantren in this matter, as Abdullah (2020) pointed out, are a form of reactive activity individually or collectively carried out to anticipate the spread of the virus.

How to cite this article: Baidowi, A., Salehudin, A., Mustaqim, A., Qudsy, S.Z. \& Hak, N., 2021, 'Theology of health of Quranic pesantren in the time of COVID-19', HTS Teologiese Studies/Theological Studies 77(4), a6452. https://doi.org/10.4102/hts.v77i4.6452

Copyright: ๑ 2021. The Authors. Licensee: AOSIS. This work is licensed under the Creative Commons Attribution License. 
Some researches have been conducted on pesantrens during the COVID-19 pandemic. These researches can at least be classified into three trends. The first type of studies examines the use of online learning technology for learning process in pesantren during the COVID-19 pandemic (Prasetia \& Fahmi 2020; Setiawan \& Rizki 2020; Wasyik \& Hamid 2020). This type of academic research on pesantren is more concerned on the learning effectiveness in pesantren during the pandemic amidst the challenging requirement to use internet technology as a learning medium. The second type closely examines the handling of pesantren in the face of the COVID-19 pandemic (Hannan, Azizah \& Atiya 2020; Prasetyo, Bashori \& Lailisna 2020; Prawoto et al. 2020; Qudsy, Awwabin \& Sholahuddin 2020). These authors believe that pesantrens play an essential and responsive role in overcoming the pandemic but have varied perspectives in interpreting the COVID-19 pandemic. The third type of studies focusses on pesantren management in the pandemic situation (Kahfi \& Kasanova 2020; Setiawan 2020). These three types of previous studies only highlight the technicaloperational dimensions of the pesantren in dealing with COVID-19, but they are yet to explain the theological views of the pesantren as the basis for making an authentic response to the COVID-19 pandemic. The views of the pesantren influence the attitudes and measurements taken in the face of the COVID-19 pandemic (Salehudin 2018).

A study that correlates theology of health of pesantren and COVID-19 serves as an essential complement to the previous researches on pesantren. Thus, this article aims to elucidate the authenticity of pesantrens' attitudes in dealing with COVID-19 pandemic based on theological values. This research delineates the strategies applied by pesantren in handling and preventing the transmission of COVID-19 amongst the santri and kyais during the pandemic. In addition, this article also points out that theological factors shape the attitudes and strategies taken by pesantrens in dealing with COVID-19. Overall, this article is directed by three objectives. Firstly, it aims to describe the theological views of the Quranic pesantrens against the COVID-19 pandemic; secondly, it analyses the underpinning reasons for the application of health protocols in the Quranic pesantrens; thirdly, it describes spiritual practices of Quranic pesantrens and their meaning as protective measures against COVID-19. These three objectives are deemed as adequate representatives of theological views of pesantren in the face of the COVID-19 pandemic.

The theological views of a community certainly affect attitudes and actions taken in the face of the COVID-19 pandemic (Ishii 2013; Tucker \& Grim 2003:xvi). This article argues that in response to the COVID-19 pandemic, pesantrens have depicted their position as a subculture that has its own rationality (Wahid 2000). Pesantrens are known to have applied authentic ways in dealing with the COVID-19 pandemic. Such method is different from that taken by general medical practitioners who tend to only provide procedural technical solutions in dealing with COVID-19.
In particular, pesantrens are known to apply a technical, procedural and spiritual approach in dealing with COVID-19. The procedural approach is conducted by adapting santri to the new health protocols, whilst the spiritual approach is carried out by the practices of Islamic spiritual rituals through prayer, dhikr (the repetitive recitation of Subhanallah, Alhamdulillah and La ilaha illa Allah, Allahu Akbar), reciting Qur'an and reciting salawat (the recitation of Allahumma salli ala Muhammad, Peace be upon Muhammad). Both views indicate the theology of pesantren, which is theocentric and anthropocentric at the same time and, thus, highlights one of the moderating sides of pesantren.

\section{Literature review Theology of health}

Religion shown its immense influence not only on the level of religiosity but also on emotions, morality and even on views that determine values and attitudes of healthy behaviours (Clobert 2021; D et al. 2014). According to Kirkpatrick (2019), religiosity and individual belief in God lead to commonplace interpretation of God as a source of protection from diseases becasue God is the only hope for providing health and healing. In line with this, Cohen (2021) emphasised that in terms of health, the essence and symbols of religious theology encourage every individual to practice healthy lifestyle, which reflects and instils obedience to God. Mosqueiro et al. (2020) stated that theology of health provides spiritual calm and peace of mind, thereby reducing the anxiety and depression levels in patients. A high personal relationship with God enables individuals to face life and diseases through theology of joy and hope (Hancock 2020). According to Eryilmaz and Kula (2020), individual health and well-being resulted from two sources of happiness, namely, (1) a personal perspective of happiness and (2) a religious perspective of happiness. In this context, the Qur'an has described how people can stay healthy and happy based on Islamic values (Eryilmaz \& Kula 2020).

The religious values have helped to shape a harmonious mindset by maintaining a well-proportioned concentration, awareness, love and wisdom in each individual (Juniartha 2017). This is in line with Shufiyah (2018) who stated that a lack understanding of religion will lead to ignorance and poor quality of life. Therefore, according to Rajab (2010), belief in theology of religions is an emotional-psychological force that turns humans into subjects who were affected by several religious dimensions, namely, (1) ritual (worship), (2) credoism (faith) and (3) norms (morals) applicable in the community. A research by William O'Neill (2017) in Africa revealed that theological understanding is of great use to transform the widely held practice of healing from traditional healing practices to theological healing practices by still taking into account their cultural practices, such as for healing emotional wounds and trauma. This is what makes theology help cure the sickness of many African women because they are hindered by cultural practices and traditions (O'Neill 2017). In line with this explanation, Rajab (2010) 
pinpointed that Islam offers a system of mental development to find solutions to the increasingly rampant social problems through tawhid (unification of God). Jauziyah stated that health theology in Islam is primarily performed in three ways: preventive, protective and curative. Jauziyah also added that the Prophet Muhammad treated a disease with two treatments: the first treatment is psychotherapy through the reading of prayers, and the second is traditional treatment using herbal medicine (Mustaqim 2012). One form of health coaching was applied by Qudsy, Masduki and Abror (2017) through the practice of fasting on Mondays and Thursdays by Muslims, which provides various virtues for physical, mental and spiritual health and serves as a way to practise patience in the interactions with the surrounding environment.

\section{Pandemic and religion}

Pandemic is an epidemic of an infectious disease occurring worldwide that leads to the highest death toll. On the one hand, Alvarez and Cardineau (2010) presented a narrative portraying how the pandemic has killed a third of Europe's population, given its highly contagious nature. On the other hand, Camus (2012), Vermeer and Kregting (2020) articulated that the outbreak of pandemic has increased the faith of religious adherents and brought them closer to God and religion. Through a religious perspective, a pandemic is sent as warning to mankind to constantly take notice on and conform to the good deeds based on religious values and teachings (Camus 2012).

As aforementioned, the large-scale outbreak of infectious diseases has implicitly been implied in the Qur'an and explicitly stated in the Hadith (Al Eid \& Arnaout 2020). Al Eid and Arnout (2020) emphasised that during a pandemic crisis as a form of widely spreading epidemic, Allah is in control, which, thus, requires our spiritual wellness as a pivotal part of protection against the widespread infectious disease and time of crises. This notion is in conformity with the opinion of Ahmad and Ahad (2020) that proper protection in the face of an epidemic shall not only cover scientific attempts but also embrace spiritual aspects. Spiritual protection is deemed crucial for providing psychological self-healing for human beings through the firm belief of God as the only power to end suffering and diseases. Pursuant to this explanation, Wujtewicz et al. (2020) highlighted that the end of 2019 has witnessed the far-reaching outbreak of COVID-19 throughout the world, which has impacted people from all walks of life. The COVID-19 pandemic is known to induce a high mortality rate because it mainly attacks the respiratory system. The case fatality rate even soars for the elderly, pregnant women and patients with symptomatic complications ( $\mathrm{Li}$ et al. 2020).

Islam denotes the substantial implication of taking care of health for the sake of the self and others (Yaqub, Rana \& Aukrust 2020). This statement implies Islamic virtues to protect mankind as a way to avoid death and diseases (Ashraf et al. 2020). Ashraf et al. (2020) then accentuated the advice of Prophet Muhammad to his friends to constantly take care of their health by warning them from visiting places with rampant spread of pandemics and epidemics. This direction is in line with the narrative presented by Ahmad and Ahad (2020), which states that the long practiced Islamic hygienical jurisprudence has regulated Muslims to maintain ritual cleanliness for their whole lives. Allah states in the Qur'an, 'And clean your clothes' (Qur'an, al-Mudatsir [74]:4) to remind Muslims to keep them clean. Muslims are required to maintain cleanliness in their daily lives through wudlu (ablution) by way of washing their hands, mouth, nostrils, arms, head and feet three times with water and ghusl (bathing) of the whole body three times with water. On this basis, Islam perceives pandemic in two perspectives. Firstly, a pandemic is a catastrophe, which 'is definitely true' according to the sunnatullah (Divine law), and it can only happen with Allah's permission (Maulana 2020). Secondly, a pandemic shall be understood as a large-scale widespread of disease. Therefore, Islam has also provided a special dispensation for children, pregnant women and patients of chronic diseases such as diabetes mellitus, kidney failure, heart disease, lung disease and cancer not to fast during Ramadhan, because people with these conditions are at high risk of the SARS$\mathrm{CoV}-2$ virus transmission during this pandemic (Yaqub et al. 2020). Syahid (2020) also expressed how mosques in Indonesia have taken physical distancing measures in congregational prayers to prevent the spread of COVID-19, which is contrast to what is performed in British Muslim community who prefer mosque closure (Al-Astewani 2021).

\section{Pesantren and pandemic}

As one of the countries with the largest Islamic education centres in the world, Indonesia has more than 10000 pesantrens, 37000 madrasas and 5.7 million madrasa santri (Tolchah \& Mu'ammar 2019). Therefore, Indonesia is home to the largest Islamic education system in the world, where thousands of Islamic schools exclusively cater to the educational needs of the children of Muslim households. Two main types of Islamic education institutions in Indonesia are madrasahs (Islamic schools) and pesantren (Islamic boarding schools) (Parker \& Raihani 2011). Pesantren is a typical Indonesian educational institution with five pillars: kyai, santri, mosques, kitab kuning (Classical Islamic books) and dormitory (Dhofier 1982; Madjid 1997). Pesantren is a form of educational institution with features distinctive from other schools. The subjects taught in pesantren are mainly hands-on subjects based on the interpretation of the santri with the kyai as the main role model and caregivers (Izfanna \& Hisyam 2012; Prawoto et al. 2020).

Pesantren is primarily established to achieve three main missions: firstly, to serve as a religious education institution; secondly, to function as a da'wah (proselytising of Islam) institution and thirdly, to act as an institution that empowers the surrounding community (Dhofier 1982). In several aspects, pesantrens serve as places to transmit the concept of moral development that are integrated with Islamic sciences (Ilyasin 2020). In line with this, pesantrens as social service 
institutions, not only play a key role in education but also take a vital part in changing the lifestyle of the community. The distinctive features of the pesantren are generally obtained from the interpretation of the santri, which become the main focus of the kyai (Izfanna \& Hisyam 2012). Given the widely ranging aspects of life (from the way of washing to trading) are learned in pesantren, the kyai is expected to provide santri with a holistic learning process by means of evaluation and orientation (Mahfudin 2020). These everyday values are known as the 'path of santri's life' (Mustafa et al. 2018).

During a pandemic crisis, pesantrens have taken their own preventive measures of SARS-CoV virus transmission as a way to survive by applying the uzlah (a Sufi term that means to avoid being with other people) technique and at-tawazun (balance) counselling (Arifin \& Zaini 2020). The uzlah techniques are similar to 'self-isolation' or 'self-quarantine' techniques. This technique is known as a proper method to break the chain of SARS-CoV virus transmission (Bodas \& Peleg 2020). Arifin and Zaini (2020) defined uzlah as the practice of isolating oneself from the fast pace of worldly matters to live in solitude with the aim of reviving the soul and purifying the thoughts of destructive influences. Arifin and Zaini (2020) added that this is in line with the genuine view of the Sufis, which primarily emphasises on the importance of sanctuary and reduces social interaction with other people. Moreover, pesantren also implements at-tawazun counselling (a form of Islamic counselling) performed based on religious values (fiqh norms and sufistic life) and the local values of the pesantren surrounding. Al-tawazun (balance) acts as an accommodative activity to maintain the mental and physical balance of the pesantren community. One of the techniques in practicing at-tawazun is riyadah batiniyah (spiritual endeavour) (by performing prayers, such as Rokat prayer [prayer to reject calamities]). Chair (2020) declared that for the Madurese community, the Rokat ritual functions as an effort to prevent diseases. Likewise, the pesantren salafiyah (pesantren Tradisional) is also renowned for the practice of Gerbat (mental movement or spiritual action known as riyadah 'ubudiyah [worship endeavour] or religious practice as a form of prayer). Gerbat is an applicable practice in pesantren to maintain mental health and to heal a wounded heart.

\section{Research method Determining research objects}

The selected research subjects consist of three pesantrens: pesantren Krapyak Bantul, pesantren An Nur Bantul and pesantren Darul Qur'an wal Irsyad Gunung Kidul. The three research objects were purposively selected by considering three criteria. Firstly, the Quranic pesantren provides general education for more than 1000 santri. The predetermined number of santri is an essential factor to allow the occurrence of mass gathering. Secondly, the pesantren is culturally affiliated with the religious organisation Nahdlatul Ulama, which practices rituals of Islamic spirituality in the face of COVID-19. Thirdly, they provide offline education, although not for the entire number of santri, which makes them vulnerable to the transmission of SARS-CoV virus.

\section{Types of research}

This is a qualitative research based on the data about the theological views of pesantren in the face of the COVID-19 pandemic. The approach used is the Phenomenology of Religion offered by Ninian Smart (2000), which looks at religious phenomena with four attitudes, namely, treating phenomena empathetically, comparing the occurring phenomena, entering the worldviews of each pesantren and using polymethodic to understand them. Empathy is relevant to the views and attitudes of pesantren towards the spread and preventive measures of SARS-CoV virus transmission. The comparison relates to distinctive attitudes of three pesantrens in dealing with the spread and preventive measures of SARS-CoV virus transmission. The world view is correlated to the doctrinal and ritual dimensions of three pesantrens in the face of COVID-19. Polymethodic emphasises the use of various methods in analysing three pesantrens in the face of COVID-19.

\section{Data collection}

The research data were obtained in three ways: observation, interviews and documentation. Firstly, observations were made to take a closer look at the actual condition in the Quranic pesantren as the research subject in conducting their offline classes in the midst of the COVID-19 pandemic. This observation was carried out to understand the learning atmosphere in three pesantrens, including the daily life of the santri, the leaflets on the information about COVID-19, hand washing facilities, bathrooms for santri, the learning process of santri, bedrooms for santri, the transition procedure for santri before entering the pesantren complex and interactions between santri and non-pesantren communities.

Secondly interviews by the researchers. They interviewed three research informants: the pesantren caregivers, the COVID-19 task force team of pesantrens and the santri. The pesantren caregivers were interviewed to reveal about pesantren views on COVID-19, pesantren policies related to the classroom learning processes and other measurements taken by pesantren to contain the SARS-CoV virus transmission. The members of pesantren COVID-19 task force were interviewed to provide information and clarification about the measurements taken by the pesantren to ensure a safe and sound learning process amidst the spread of COVID-19. Santri were also interviewed to find out how they respond to the various regulations made by the pesantren.

Thirdly, documentation in this study encompasses all documents related to COVID-19, such as pesantrens' decisions regarding the instructions for santri to return home, various appeals about health protocols and pesantrens' policies related to reopening of the teaching and learning process. The documentation also took the form of photos of the daily activities of santri at the pesantrens, the copy of prayers' 
recitation, salawat and hizib recited for the rituals of Islamic spirituality. This documentation serves as an authentic evidence of pesantrens' policies in the face of the COVID-19 pandemic.

\section{Data analysis}

The analysis was started since the beginning of the study, even shortly after determining the research topic. This process makes it different from quantitative research which places analysis as the last step in the research process after the data collection. Data analysis was carried out by sorting and selecting data related to pesantren theological views, implementation of health protocols and rituals of Islamic spirituality carried out by the pesantren. This study treats all data and information as equally essential. In other words, no data is positioned as determinant because everything complements each other. Every policy of the pesantren regarding the implementation of offline education is closely related to the values shared by each of these pesantrens. Therefore, the analysis aims to disclose the concealed meaning behind every action.

\section{Results}

This study presents three important findings: the views of pesantrens on the COVID-19 pandemic, the applicable adaptation and modification of health protocols and rituals of Islamic spirituality to deal with the COVID-19 pandemic.

\section{The views of the Quranic pesantrens on the coronavirus disease 2019 pandemic}

Three Quranic pesantrens, namely, Krapyak, An Nur Ngrukem and Darul Qur'an wal Irsyad Gunung Kidul share the same opinion about the fact that the outbreak of COVID-19 is for real. In other words, they do believe that it is not a myth or a conspiracy as some others who shared doubts about its existence (https://www.cnnindonesia.com). Overall, the Quranic pesantrens share three distinctive views on the outbreak of COVID-19 (Table 1). Firstly, they deem the COVID-19 pandemic as a catastrophe that may befall upon anyone, both believers and non-believers, including the Quranic pesantrens. This accident can only occur because of the will of Allah, as mentioned in the Qur'an, al-Hadid [57]:22, so that people learn about the meaning of patience. Everyone is prone to the transmission of SARS-CoV virus, and at the same time has the ability to avoid it by putting their best efforts in conducting the following steps: maintaining cleanliness, complying with health protocols and having patience (Qur'an, al-Baqarah, [2]:45) and tawakkal (surrendering fully to God) (Qur'an, al-Talaq [65]:3).

Secondly, the COVID-19 pandemic is seen as a bala' (an ordeal), which is unavoidable in human life, as mentioned by Abdul Haris, Khairun Niat and Nilzam. Bala' was intentionally sent down by Allah SWT in order to test one's faith and level of patience, as stated in the Qur'an, alBaqarah [2]:155. The COVID-19 pandemic is an ordeal that can befall everyone, good and bad person, including kyais and hafizs (Qur'an memorisers). Like other pandemics, there is no cure for COVID-19 and there is no exact prediction when it will go away. However, it is necessary to take some preventive measures to contain the transmission of COVID-19 pandemic, amongst others by way of self-isolation. This method of preventive measure against the outbreak of diseases is clearly stated in the hadith of the prophet: people who are residing in an area with the outbreak of a disease shall not leave the area, and people who are residing outside the area shall not enter the area with the pandemic. Even if you have taken the preventive measures, you still contract COVID-19, and this is the destiny of Allah. Then if eventually the person exposed to COVID-19 dies, he is a martyr, as mentioned in the 'sahih hadith (valid tradition of Prophet Muhammad)'.

Thirdly, COVID-19 is perceived as both a catastrophe and an ordeal for all mankind. This is evidenced by the fact of the high rate of death because of SARS-Cov virus transmission, and the larger number of infected patients, including those who memorised the Qur'an. On this basis, there is no way for all mankind but to put their best effort to avoid the spread of SARS-CoV virus (ikhtiar or endeavour) and surrender fully to God for protection (tawakkal or surrender to God). To anticipate the ups and downs of the degree of tawakkal (surrender), one needs to implement strict health protocols, such as by wearing masks, maintaining cleanliness and implementing physical distance against the crowd. Such health protocols are well applied in the pesantren, as Abdul Haris articulated, 'At the Darul Qur'an, we apply two approaches: increasing the amount of time for dhikr and applying strict health protocols'. This is in accordance with the moderate view of Nahdlatul Ulama, which stands in the middle by way of synergising between the concept of tawakkal (surrender) and ikhtiar (endeavour). More than that, the Darul Qur'an considers COVID-19 as a blessing, 'since it provides a way for the pesantren to better apply Islamic principles, such as environmental cleanliness, social care and the adoption of a healthy lifestyle'.

As an ordeal and catastrophe, the outbreak of COVID-19 is deemed to comprise wisdom and grace, so that people can help each other and maintain cleanliness. Nilzam revealed that on the one hand, COVID-19 generates wisdom as it encourages humans to stay humble (tawad $u^{\prime}$ ) instead of being arrogant, and urges people to help each other, especially the patients infected with SARS-CoV virus. On the other hand, COVID-19 serves as a blessing because those who die on the attempt to recover from the illness will become a martyr, as Khoirun Niat pronounced.

\section{Health protocols in the Quranic pesantrens}

As President Jokowi called for social restrictions with effect from 15 March 2020, there had been a less conducive learning atmosphere in the Quranic pesantrens. The 
TABLE 1: The views of the Quranic pesantrens on the coronavirus disease 2019 pandemic.

\begin{tabular}{|c|c|c|c|}
\hline $\begin{array}{l}\text { Views on } \\
\text { COVID-19 }\end{array}$ & Implications & Attitudes & References \\
\hline Catastrophe & $\begin{array}{l}\text { Everyone is prone to } \\
\text { the SARS-CoV virus } \\
\text { transmission but } \\
\text { preventive } \\
\text { measurements can } \\
\text { be taken. } \\
\text { It is necessary to } \\
\text { learn about the } \\
\text { meaning of patience. }\end{array}$ & $\begin{array}{l}\text { The transmission of } \\
\text { SARS-CoV virus can } \\
\text { be avoided by } \\
\text { putting the best } \\
\text { endeavours, such } \\
\text { as by way of } \\
\text { maintaining } \\
\text { cleanliness and } \\
\text { complying with strict } \\
\text { health protocols. }\end{array}$ & $\begin{array}{l}\text { Qur'an, al-Hadid } \\
\text { [57]:22; Qur'an, } \\
\text { al-Baqarah, [2]:45; } \\
\text { Qur'an, al-Talaq } \\
\text { [65]:3. }\end{array}$ \\
\hline $\begin{array}{l}\text { Bala' } \\
\text { (an ordeal) }\end{array}$ & $\begin{array}{l}\text { Everyone is prone } \\
\text { to the transmission, } \\
\text { including those } \\
\text { who memorise } \\
\text { the Qur'an. } \\
\text { The spread of } \\
\text { disease is meant } \\
\text { to test the degree } \\
\text { of faith. }\end{array}$ & $\begin{array}{l}\text { The disease can } \\
\text { only go away on } \\
\text { Allah's will. } \\
\text { It is suggested to } \\
\text { intensify our } \\
\text { efforts for dhikr } \\
\text { and prayers. }\end{array}$ & $\begin{array}{l}\text { Qur'an, al-Baqarah } \\
\text { [2]:155. }\end{array}$ \\
\hline $\begin{array}{l}\text { Both } \\
\text { catastrophe } \\
\text { and ordeal }\end{array}$ & $\begin{array}{l}\text { Everyone is prone to } \\
\text { the transmission, } \\
\text { and he or she may } \\
\text { recover or die. } \\
\text { COVID-19 is sent } \\
\text { down to test the } \\
\text { faith and patience. }\end{array}$ & $\begin{array}{l}\text { It shall be faced with } \\
\text { the best endeavour } \\
\text { to avoid the } \\
\text { transmission (health } \\
\text { protocols) and by } \\
\text { surrendering fully to } \\
\text { God (tawakkal), } \\
\text { prayer and dhikr. }\end{array}$ & $\begin{array}{l}\text { Qur'an, al-Hadid } \\
\text { [57]:22; Qur'an, } \\
\text { al-Baqarah, [2]:45; } \\
\text { Qur'an, al-Talaq } \\
\text { [65]:3. }\end{array}$ \\
\hline
\end{tabular}

COVID-19, the coronavirus disease 2019.

situation was worsened by the dramatic increase in confirmed cases of COVID-19, including in Yogyakarta (https://www.liputan6.com) and mostly because of the inaccurate media coverage (https://bisnis.tempo.co). Given this condition, Pondok Krapyak and Darul Qur'an wal Irsyad decided to halt the learning process and send their santri' home on 21 and 22 March 2020, whilst An-Nur Ngrukem did the same on 23 March 2020. This measurement was taken by the pesantrens for three reasons. Firstly, it was carried out to accommodate the number of requests from the parents of the santri to send the santri home for the sake of their safety. Secondly, the measurement was taken to meet the recommendation from the government. Thirdly, it was performed to comply with the circular letter from the PBNU (The Nahdlatul Ulama Central Board) Rabitah Ma'ahid Islamiyah (RMI or Assosiation of Islamic pesantren), advising the pesantrens to send their santri home, as indicated by the interview with the three pesantrens' COVID task force.

The pesantrens mainly apply two methods to send their santri home. Firstly, the parents or guardians with a letter of authority are required to pick up the santri.

Those who were allowed to pick the santri up were the families of the santri and/or guardians as stated by a letter of authority from the parents of the santri. There were 2 posts for picking up the santri, namely the pick-up post for male santri and the pick-up post for female santri. Pickers were prohibited from entering the pesantren area, and thus were only permitted to wait outside the front gate of the pick-up post. (male, 26 years old, COVID team in pesantren; female, 42 years old, pesantren leader; female, 41 years old, teacher)

Secondly, santri were escorted to their respective areas using rented cars.

The management grouped the santri based on their area of origin and drove them to their respective homes using a rented car.
Thus, the santri could go home using the same vehicle with their fellow santri who come from the same area. (male, 46 years old, teacher)

These two methods of sending the santri home are expected to ensure that santri will arrive at their respective homes safe and sound as a way to avoid the transmission of SARS-COV virus.

However, after about 2 months, the santri being home, four new problems emerged. Firstly, countless number of parents worried about the negative circle of friends in their surrounding environment at home that might affect their children, in addition to the negative effects of the uncontrolled use of gadgets. Secondly, the santri were fed up with staying at home for too long without having any effective learning activities. Thirdly, there had been an increasingly ineffective process of memorising the Qur'an for the santri with the online model. The use of online technology enabled the santri to 'manipulate' their mastery of Quranic verses. For instance, 'The santri were seemed fluent during the recitation of Qur'an memorization because they directly read the Quran placed in front of them, instead of memorizing it' (An interview with Esti Wuryanti and Akhyar). Fourthly, the community living in the surrounding environment of pesantrens were suffering from deprived welfare and economic hardship as the santri returned home. These four problems underpin the reason for pesantrens to ask the santri to return to pesantrens.

Despite the alarming number of confirmed cases, pesantrens decided to start the offline teaching and learning process at pesantrens by complying with the COVID health protocol. Prior to the offline learning implementation, pesantrens were required to obtain official permission from the government for the offline learning to take place, even though it was not made fully effective. Offline learning official permission is only granted to pesantrens with a full supporting system for implementing health protocols, such as the COVID-19 task force, quarantine places and the standard learning process during the COVID-19 pandemic.

The santri returned to pesantrens in stages based on the capacity of the quarantine room of pesantren. Before departing to pesantrens, the santri were required to have a self-quarantine at homes for 2 weeks and upon their arrival at pesantrens they had to undergo another 14 days of self-quarantine before carrying out their daily activities in pesantrens.

Prior to the quarantine process at the pesantrens, the santri were screened and were required to apply strict health protocols, such as bathing and changing clothes, washing dirty clothes in a destined laundry. (male, 39 years old, pesantren leader; male, 26 years old, COVID team in pesantren)

Having completed the quarantine period at pesantrens for 14 days, the santri began to do their regular activities in pesantrens, just like the regular activities before the strike of COVID-19. The only difference lies at the requirement to apply strict health protocols in all activities. For instance, 
santri were required to wear masks during the learning activities or when participating in other activities, such as performing arts and beauty contests. In addition, the pesantrens also forbade santri from making a direct contact with outsiders, including the parents of the santri. According to Amiq and Yustin Amalia,

Santri were prohibited from interacting with parties outside pesantrens, even the guardians were not allowed to visit santri. Instead, the regular visit session was replaced with virtual visit. Violating this policy means the santri have to return home. (female, 22 years old, teacher)

The same rules also apply to other Quranic pesantrens.

To keep their immune system, santri are required to do some activities for fun as a way to keep them happy and cheerful, such as miscellaneous sports, gymnastics, sunbathing, the practice of creative writing (poetry and short stories) and painting. Moreover, pesantrens also improve the santri's diet by adding some nutrients, such as side dishes and milk (Amiq, Yustin and Esti).

\section{Spiritual protective measures from the coronavirus disease 2019}

The coronavirus disease 2019 is a creature sent by Allah that operates according to His commands. If Allah has predestined someone to be infected by the virus, he would still contract the disease no matter what he did to protect himself, even if he applied strict health protocols against SARS-CoV virus. Likewise, a person who contracts the disease will not certainly die if he is not destined to die. On this basis, apart from adopting strict health protocols as a contextual protective measure, pesantrens also apply spiritual protective measures against the spread of SARS-CoV virus.

Three pesantrens have applied their own distinctive spiritual protective measures (Table 2), which ranged from prayers, salawat recitation and hizib. The different types of spiritual protective measures are entirely depended on two aspects: the traditional rituals of Islamic spirituality in each pesantren and the rituals specifically prescribed by the pesantrens' caregivers in the face of the COVID-19 pandemic.

For instance, pesantren An-Nur regularly applies three rituals to ward off the spread of COVID-19. Firstly, santri are required to intensify salawat recitation for the Prophet which reads Allahumma Shalli ala Sayyidina Muhammad wa 'ala Alihi wa Ashhabihi ajma'in (literary meaning: O Allah, give mercy (compassion) and salvation to the Prophet Muhammad) after each Fardhu (obligatory) prayer. Secondly, santri shall recite thibbil qulub salawat (prayer for healing of illness) regularly after performing the Asr prayer. Thirdly, santri are encouraged to recite more Istighfar (ask God for mercy). People who recite salawat and istighfar are believed to be protected by Allah from the SARS-CoV virus, as Allah says in the Qur'an, al-Anfal (8):33, And Allah would not punish them while you were amongst them. Allah will not punish them (either) while yet they ask for forgiveness. 'If in the past the physical presence of Prophet Muhammad prevented people from punishments (adhab), the recitation of salawat is an effort to present the Prophet Muhammad to protect us against the escalating spread of the COVID-19 transmission in the nearby surrounding,' said Niat (male, 39 years old, pesantren leader).

TABLE 2: Spiritual protective measures from the coronavirus disease 2019.

\begin{tabular}{|c|c|c|}
\hline Pesantren & Time & Recitation \\
\hline \multirow[t]{10}{*}{ Krapyak } & \multirow[t]{5}{*}{ Maghrib } & Asma' bismil (Prayer to reject calamities) one time \\
\hline & & The Qur'an, Al-Ikhlas three times \\
\hline & & The Qur'an, al-Falaq one time \\
\hline & & The Qur'an, al-Nas one time \\
\hline & & Ayat Kursi (Al-Baqarah, 255), one time \\
\hline & \multirow[t]{2}{*}{ After five prayers (Fardlu prayers) } & Salawat tola' bala one time \\
\hline & & The Qur'an, al Insyirah seven times \\
\hline & After Maghrib and Shubuh prayers & Hasbiya Allah (Allah is sufficient for me), 10 times \\
\hline & At any time or not restricted to a certain schedule & Shalat sunnah mutlak (additional prayers that are not bound by time) \\
\hline & Drinking water & Recitation of prayers for the drinking water \\
\hline \multirow[t]{3}{*}{ Pesantren An-Nur } & \multirow[t]{2}{*}{ Every Ashr } & Recitation of Ratb al-Haddad (the name of a collection of prayers), as many as possible \\
\hline & & Recitation of Salawat Thibbil Qulub (asking for health), as many as possible \\
\hline & At any time & Recitation of Salawat Muhammadiyah (prayer to the prophet Muhammad) as many as possible \\
\hline \multirow{7}{*}{$\begin{array}{l}\text { Pesantren Darul } \\
\text { Qur'an wal Irsyad }\end{array}$} & After Shubuh prayer & Wirid Latif, Ratib al-Imam and Hizib Nawawi (the name of a collection of prayers), one time \\
\hline & After five prayers (Fardhu prayers) & Hizib bahr (Prayer asking Allah for help), one time \\
\hline & After Maghrib prayer & Ratib Haddad (the name of a collection of prayers), one time \\
\hline & Morning ceremony & Asmaul Husna (the names of Allah) and hizib bahar (Prayer asking Allah for help), one time \\
\hline & Prior and After Shalat Tahajjud & Asmaul Husna, (the names of Allah) one time \\
\hline & Tuesday evening & $\begin{array}{l}\text { Salawat Muhammadiyah (prayer to the prophet Muhammad) and Burdah (prayers and praise for } \\
\text { the Prophet Muhammad) one time. }\end{array}$ \\
\hline & Thursday evening & $\begin{array}{l}\text { Tahlil (the recitation of La ilaha illa Allah), The Qur'an, Yasin; Maulid al-Barzanji (praise to the } \\
\text { prophet's family), one time }\end{array}$ \\
\hline
\end{tabular}


Pesantren Krapyak applies two types of Islamic rituals: the ritual in congregation and individual rituals. The rituals in congregation are conducted after maghrib prayer by reciting Bismillahi La ya dhurru Ma'a ismihi syay'un fi al-ardh wa la fi al-sama wa huwa al-sami 'al-alim (Prayer asking God for protection), one time, The Qur'an, al-Ikhlas three times, al-Falaq once, Al-Nas once and Ayat Kursi once. After each fardhu prayer, santri recites Allahumma Shalli 'ala sayyidina Muhammad wa 'ala Ali sayyidina Muhammad Sholatan tadfa'u biha 'anna altha 'na wa al-tha 'un ya man arada syai' an an yaqula lahu kun fayakun (salawat recitation to reject the pandemic) (11 times, in addition to the unrestricted recitation of the thibbil qulub (recitation asking for health) prayer. The individual ritual of spirituality includes the recitation of Surah al-Insyirah seven times after each Fardhu prayer, recitation of the hasbiya Allah La ilaha illa Huwa 'alaihi tawakkaltu wa huwa rabbul' arsy al-'azhim (Surrender prayer to God) and 10 times after Maghrib prayer and Shubuh prayer and performing Sunnah Mutlaq prayers (additional prayers that are not bound by time) and $d h i k r$ (Islamic recitation to remember God). The recitation in the prescribed rituals is derived from the ijazah (a prescribed recitation) from two religious women leaders, Ida Fatimah Zainal and Hannah from Lirboyo Kediri. In addition to these readings, santri are also provided a drinking water containing the prayers as part of protective measurements from the COVID-19 outbreak. (female, 42 year old, pesantren leader; male, 46 years old, pesantren leader; female, 22 years old, teacher)
When a santri is confirmed COVID-19 positive, the intensity of the ritual is increased and another recitation is added. They perform the prayer rituals after all 5 times of Fardhu Prayers, recite the thibbil qulub prayer 7 times and al-Fatihah 3 times by repeating the verse iyyaka na'budu wa iyyaka nasta in (You 'alone' we worship and You 'alone' we ask for help) 11 times, whilst inwardly intending to ask Allah for recovery. This practice is believed to strengthen the body's immune system and a form of healing treatment. Given these rituals, all santri who were confirmed positive could recover from the disease, even though the recovery time varied. Some santri immediately recovered after three days, some recovered in seven days, some even took up to fourteen days to recover (an interview with Yustin).

Pesantren Darul Qur'an wal Irsyad practices several kinds of rituals as protective measurements against the outbreak of COVID-19 (Figure 1), namely, (1) Wirid Latif, Rotib Imam and Hizib Nawawi (the name of a collection of prayers), recited one time after the Fajr prayer, (2) hizib bahr (Prayer asking Allah for help) recited one time after the Fardhu prayer, (3) Ratib Haddad (the name of a collection of prayers) recited one time after Maghrib prayer, (4) Asmaul Husna (The names of Allah) and hizib bahr recited one time in every morning ceremony before starting the daily activities in pesantren, (5) Asmaul Husna one time before and after the midnight prayer, (6) Salawat Muhammadiyah and Burdah every Tuesday evening and (7) Tahlil (the recitation of La ilaha illa Allah),

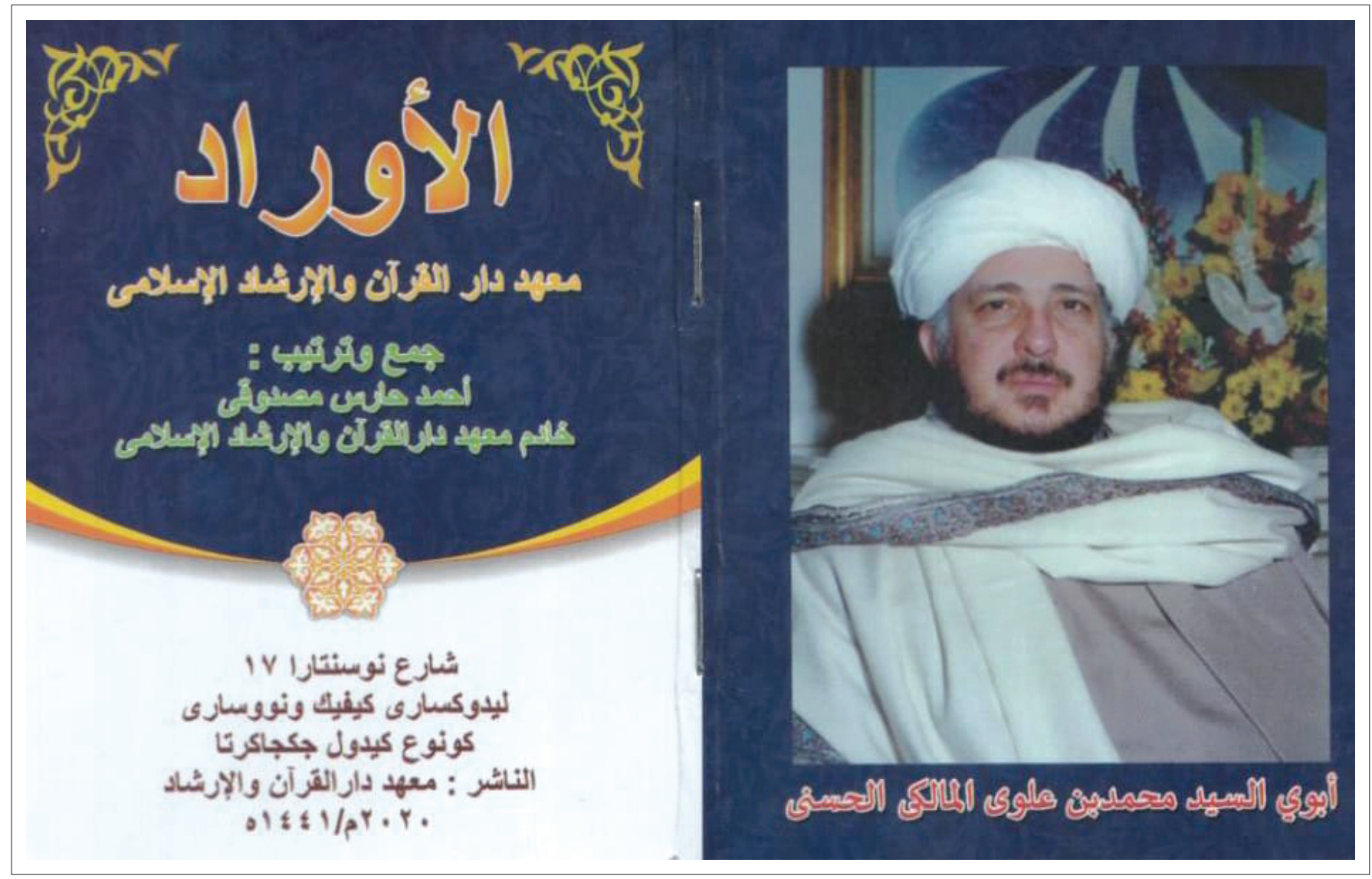

Source: Darul Qur'an Islamic Boarding School

FIGURE 1: Collection of prayers recited at the Darul Qur'an Islamic Boarding School. 
Yasin and Maulid al-Barzanji (praise to the family of the Prophet Muhammad) every Thursday evening. These readings are a prescribed recitation from Sayyid Alwi AlMaliki as a teacher of $\mathrm{KH}$ Kharis Marzuki, caretaker of Pesantren Darul Qur'an wal Irsyad (an interview with Akhyar and Esti Wuryani).

\section{Discussion}

This research shows the distinctive and unique mechanism of pesantrens in dealing with the COVID-19 pandemic. This fact is indicated by three points. Firstly, COVID-19 is a catastrophe and an ordeal for all mankind that must be addressed with the best physical and mental effort. Secondly, such effort is applied in the health protocols applied by pesantrens whilst sending the santri home at the early outbreak of the COVID-19, the procedures to welcome santri who return to pesantrens, the learning process and the daily life of the santri at the pesantrens during the pandemic situation. The applicable health protocols are adjusted according to the needs and local context of each pesantren. Thirdly, pesantrens also apply spiritual endeavours through the recitation of certain verses in the Qur'an, prayers, hizib (a collection of certain prayers) and recitation of prayers for drinking water. These three points indicate the comprehensive approach of Quranic pesantren in dealing with COVID-19. This practice confirms what has been shown by Cohen (2021) and Mosqueiro et al. (2020) that religion, in this case pesantren, emphasises theology of health in providing students with spiritual calm and peace. It also strengthens Sam D. Gill's notion that the Qur'an as a holy book, not only has an informative function but also has a performative function. Whilst the first function emphasises on the instructions of the Quranic verses to maintain health, the second concerns on the practice of using the verses of the Qur'an as a means of healing through recitation and writing. It is clear that the spiritual practices applied by the santri of the three pesantrens act as the performative function of the Qur'an (Denny \& Taylor 1985).

The comprehensive approach of these pesantrens in dealing with COVID-19 is a manifestation of authentic faith shared by many pesantrens. This authenticity is obtained from the viewpoint of these Quranic pesantrens that SARS-CoV virus is Allah's creature who only works on His orders. This view pinpoints a synergy between divine and worldly reasoning amongst pesantrens in responding to SARS-CoV virus. Worldly reasoning is demonstrated by the contextual application of health protocols to avoid the malignancy of SARS-CoV virus. Meanwhile, divine reasoning is reflected in the implementation of prayer - Islamic rituals of spirituality. These rituals, as also mentioned by Chair (2020), are intended to shape an attitude of patience and submission which is believed to increase body immune system as a protective measure against the spread of SARS-CoV virus. This fact proves that Quranic pesantrens have their own distinctive systemic and comprehensive view and way of dealing with SARS-CoV virus, which is different from the widely shared medical perspective that positions SARS-CoV virus as a threat to be contained, controlled and conquered with the injection of COVID-19 vaccine.

The comprehensive and systemic approach of three pesantrens in the face of the COVID-19 pandemic illustrates that pesantrens - to borrow a quote from Evans-Pritchard (1965) and Salehudin (2018) - have their own rationality. This rationality is obtained from the worldviews of the Quranic pesantrens in attempting to regain their daily regular activities as in the normal condition. The shared belief of these Quranic pesantrens that SARS-CoV virus is a God's creature and only works according to His orders makes them apply a different measurement from the general health protocols and government policies. These measurements prevent these Quranic pesantrens from excessive fear about the spread of SARS-CoV virus because the spread of the virus will only take place in accordance with Allah's will and orders. Nonetheless, they consider that modified health protocols and special rituals of necessity as a manifestation of patience and endeavour against the ordeal and catastrophe sent down by Allah.

The distinctive feature of this study when compared with the previous studies on COVID-19 lies on the uniqueness of Quranic pesantrens as a subculture that have their own way of coping with the spread of SARS-CoV virus. Whilst the previous studies were inclined to address the correlation between the spread of SARS-CoV virus and pesantren in terms of management, learning models and economic empowerment in the time of COVID crisis, this study showcases the theology of health of Quranic pesantren based on local wisdom and creativity in dealing with COVID-19. The distinctive protective measurements against the spread of COVID-19 applied by Quranic pesantrens indicate their own meaningful values and their own theology of health which prevent pesantrens from excessive worries in living a normal life amidst the COVID-19 pandemic.

The theology of health of these pesantrens may serve as an alternative role model for the public at large in dealing with the spread of SARS-CoV virus in a rational, productive and innovative manner. On this basis, the theology of health model of pesantren may be deemed as a considerable alternative to be included in government policy in dealing with the transmission of COVID-19. This policy allows the government to touch the spiritual aspect of the public to prevent them from excessive fear about this pandemic.

\section{Conclusion}

The results of this study denote that the theology of health of pesantren is an appropriate reference for other pesantrens in Yogyakarta in the face of the COVID-19 pandemic. Three Quranic pesantrens in Yogyakarta applied a comprehensive approach through modified health protocols adjusted to the local context of the pesantren. In addition, they also performed spiritual endeavours by reciting the verses of the Qur'an, salawat of the Prophet, hizib and prayers. This approach was 
taken based on the view shared by these Quranic pesantrens that COVID-19 is a divine being who works only on His orders. The distinctive protective measures taken by these Quranic pesantrens are a manifestation of the pesantren as a subculture that has its own local wisdom in dealing with the COVID-19 pandemic. This point delineates a transformation of health theology amongst pesantrens. Prior to the COVID-19 pandemic, pesantrens tended to apply a nearly fatalistic theological view, but the numerous victims of COVID-19 have turned the fatalistic theological view of the pesantren into a rational-transformative theological view as indicated by the external and internal efforts of pesantren in dealing with COVID-19 (https://www.duniasantri.co/suddenlyjabariyah/).

The results of this study serve as a beneficial input for policymakers in formulating a comprehensive strategy in dealing with the COVID-19 pandemic. Efforts to tackle the COVID-19 pandemic shall not only adhere to technical, procedural and medical health protocols but also embrace the spiritual values adopted in society. It is essential to apply this strategy to avoid community resistance in the policymaking regarding the handling of the COVID-19 pandemic. This way is expected to urge community participation through efforts in coping with COVID-19 with a better efficacy.

Nevertheless, this study has two limitations: firstly, it only examines three pesantrens located in Yogyakarta and, secondly, it excludes the surrounding community of the pesantrens. Thus, it is expected that further research will consider examining some non-Quranic pesantrens located in Yogyakarta and outside Yogyakarta, especially pesantrens which become the clusters of the COVID-19 pandemic. This way is projected to generate more reliable picture as an approach to formulate the theology of the health of pesantrens.

\section{Acknowledgements}

The authors thankfully acknowledge the informants Maya, Nilzam, Khoniq, Haris, Esti, Akhyar, Khairun Niat, Bahrul Amiq, Hubab Naufal and Nurus Sa'adah.

\section{Competing interests}

None of the authors of this study has a financial or personal relationship with other people that could inappropriately influence or bias the content of the study.

\section{Authors' contributions}

All listed authors contribute to this article. A.B. wrote the original draft, reviewed and edited it. A.S. conceptualised the study and managed the project administration. A.M. was responsible for the methodology and validation. S.Z.Q. wrote the formal analysis and compiled the resources. N.H. wrote the visualisation and supervised the project.

\section{Ethical considerations}

This article followed all ethical standards for research, without direct contact with human or animal subjects.

\section{Funding information}

This research received no specific grant from any funding agency in the public, commercial or not-for-profit sectors.

\section{Data availability}

Data sharing is not applicable to this article as no new data were created or analysed in this study.

\section{Disclaimer}

The views and assumptions expressed in this article are those of the authors and do not necessarily reflect the official policy or position of any affiliated agency of the authors.

\section{References}

Abdullah, I., 2020, 'COVID-19: Threat and fear in Indonesia', Psychological Trauma: Theory, Research, Practice, and Policy 12(5), 488-490. https://doi.org/10.1037/ tra0000878

Ahmad, Z. \& Ahad, A., 2020, 'COVID-19: A study of Islamic and scientific perspectives', Theology and Science 19(1), 32-41. https://doi.org/10.1080/14746700.2020.18 25192

Al-Astewani, A., 2021, 'To open or close? COVID-19, mosques and the role of religious authority within the British Muslim community: A socio-legal analysis', Religions 12(1), 11. https://doi.org/10.3390/rel12010011

Al Eid, N.A. \& Arnout, B.A., 2020, 'Crisis and disaster management in the light of the Islamic approach: COVID-19 pandemic crisis as a model (a qualitative study using the grounded theory)', Journal of Public Affairs 20(4), e2217. https://doi. org/10.1002/pa.2217

Alvarez, M.L. \& Cardineau, G.A., 2010, 'Prevention of bubonic and pneumonic plague using plant-derived vaccines', Biotechnology Advances 28(1), 184-196. https://doi.org/10.1016/j.biotechadv.2009.11.006

Arifin, S. \& Zaini, A., 2020, 'Decision of implementing Uzlah and Gerbat techniques in Islamic boarding school as preparedness response for COVID-19 pandemic', Unnes Journal of Public Health 9(2), 126-134. https://doi.org/10.15294/ujph.v9i2.38107

Ashraf, H., Faraz, A., Raihan, M. \& Kalra, S., 2020, 'Fighting pandemics: Inspiration from Islam', Journal of the Pakistan Medical Association 70(Suppl 3), S153-S156. https://doi.org/10.5455/JPMA.34

Bodas, M. \& Peleg, K., 2020, 'Self-isolation compliance in the COVID-19 era influenced by compensation: Findings from a recent survey in Israel', Health Affairs 39(6), 936-941. https://doi.org/10.1377/hlthaff.2020.00382

Camus, A., 2013, Sampar, transl. NH Dini, Penerbit Obor, Jakarta.

Chair, B.M., 2020, 'Dimensi Kosmologis ritual Rokat Pandhaba pada Masyarakat Madura', Jurnal SMART 6(1), 127-141. https://doi.org/10.18784/smart.v6i1.952

Clobert, M., 2021, 'East versus west: Psychology of religion in East Asian cultures', Current Opinion in Psychology 40, 61-66. https://doi.org/10.1016/j. copsyc.2020.08.021

Cohen, A.B., 2021, 'You can learn a lot about religion from food', Current Opinion in Psychology 40, 1-5. https://doi.org/10.1016/j.copsyc.2020.07.032

Denny, F.M. \& Taylor, R.L., 1985, The holy book in comparative perspective, University of South Carolina Press, Columbia, SC.

Dhofier, Z., 1982, Tradisi Pesantren: Studi tentang Pandangan Hidup Kyai, LP3ES, Jakarta.

Dhofier, Z., 1994, Tradisi Pesantren: Studi tentang Pandangan Hidup Kyai, 6th edition, LP3ES, Jakarta.

Eryilmaz, A. \& Kula, N., 2020, 'An investigation of Islamic well-being and mental health', Journal of Religion and Health 59, 1096-1114. https://doi.org/10.1007/ s10943-018-0588-0

Evans-Pritchard, E.E., 1965, Theories of primitive religion, Oxford University Press, London.

Hancock, V.R., 2020, 'Developing a theology of joy: A personal exploration using narrative accounts - Learning to sing in a foreign land', Journal of Disability and Religion 24(3), 317-331. https://doi.org/10.1080/23312521.2020.1750534

Hanna, A., Azizah, S. \& Atiya, H., 2020, 'Dinamika Pesantren Dalam Merespons Pandemi COVID-19 Di Madura', DINIKA: Academic Journal of Islamic Studies 5(2), 213-242. https://doi.org/10.22515/dinika.v5i2.2923 
Ilyasin, M., 2020, 'Transformation of learning management: Integrative study of Islamic boarding school curriculum', Dinamika IImu 20(1), 13-22. https://doi. org/10.21093/di.v20i1.2006

Ishii, M., 2003, Cherry blossoms and lily: Comparing the understanding of death and resurrection in the traditional Japanese view and Christian teaching, ProQuest Information and Learning Company, Ann Arbor.

Izfanna, D. \& Hisyam, N.A., 2012, 'A comprehensive approach in developing akhlaq: A case study on the implementation of character education at Pondok Pesantren Darunnajah', Multicultural Education and Technology Journal 6(2), 77-86. https:// doi.org/10.1108/17504971211236254

Juniartha, M.G., 2017, 'Teknik Meditasi pada Perkumpulan bai Usada di Denpasar Sanur Kauh kecamatan Denpasar Selatan Kota Denpasar (Kajian Teologi Kesehatan Hindu)', Jurnal Penelitian Agama 3(1), 26-47.

Kahfi, S. \& Kasanova, R., 2020, 'Manajemen Pondok Pesantren Di Masa Pandem COVID-19', Pendekar: Jurnal Pendidikan Berkarakter 3(1), 26-30.

Kirkpatrick, L.A., 2019, 'An attachment-theory approach to the psychology of religion', in B. Spilka \& D.N. Mclntosh (eds.), The psychology of religion, pp. 114-133, Routledge, New York, NY.

Li, X., Xu, S., Yu, M., Wang, K., Tao, Y., Zhou, Y. et al., 2020, 'Risk factors for severity and mortality in adult COVID-19 inpatients in Wuhan', Journal of Allergy and Clinical Immunology 146(1), 110-118. https://doi.org/10.1016/j. jaci.2020.04.006

Madjid, N., 1997, Bilik-Bilik Pesantren, Paramadina, Jakarta.

Mahfudin, M., 2020, 'Tradisi 'Nyewu Salawat' di Pondok Pesantren Miftakhul Jannah Kalipucang Kulon Batang', Jurnal Living Hadis 5(2), 221-235.

Maulana, A.M.R., 2020, 'Pandemi dalam Worldview Islam: Dari Konsepsi ke Konspirasi', Tribakti: Jurnal Pemikiran Keislaman 31(2), 307-323. https://doi. org/10.33367/tribakti.v31i2.1232

Mosqueiro, B.P., Caldieraro, M.A., Messinger, M., Da Costa, F.B.P., Peteet, J. \& Fleck, M.P. de A., 2020, 'Religiosity, spirituality, suicide risk, and remission of depressive symptoms: A 6-month prospective study of tertiary care Brazilian patients', Journal of Affective Disorders 279, 434-442. https://doi.org/10.1016/j. jad.2020.10.028

Mustafa, M., Yudono, A., Wikantari, R. \& Harisah, A., 2018, 'Implementation of Islamic values in houses around Darul Istiqamah Islamic boarding school in Maccopa, Maros', Pertanika Journal of Social Sciences and Humanities 26(4), 2731-2746.

Mustaqim, A., 2012, 'Argumentasi Tradisi Pengobatan Nabi', in S. Syamsuddin (ed.), Islam, Tradisi dan Peradaban, pp. 283-304, Bina Mulia Press, Yogyakarta.

O'Neill, W.D., 2017, 'Toward a fuller view: The effect of globalized theology on an understanding of health and healing', Missiology: An International Review 45(2), 204-214. https://doi.org/10.1177/0091829616684863

Parker, L. \& Raihani, R., 2011, 'Democratizing Indonesia through education? Community participation in Islamic Schooling', Educational Management Administration and Leadership 39(6), 712-732. https://doi. org/10.1177/1741143211416389

Prasetia, S.A., \& Fahmi, M., 2020, 'Reorientasi, Peran dan Tantangan Pendidikan Islam di Tengah Pandemi', Tarbawi: Jurnal Pendidikan 9(1), 21-37.

Prasetyo, M.A.M., Bashori, B. \& Lailisna, N.N., 2020, 'Strategy of boarding school (Pesantren) education in dealing with the COVID-19 pandemic', Khalifa: Journal of Islamic Education 4(2), 142-160.

Prawoto, I., Rohmah, S.N. \& Sunarya, F.R., 2020, 'Peran Preventif Pemimpin Dalam Pencegahan Penyebaran COVID-19; Strategi Syaykh Al-Zaytun di Ma'had AlZaytun dan Kontribusinya Terhadap Masyarakat Sekitar', SALAM: Jurnal Sosial Dan Budaya Syar-i 7(5), https://doi.org/10.15408/sjsbs.v7i5.15571

Qudsy, S.Z., Awwabin, M.R. \& Sholahuddin, A., 2020, 'Temboro Tablighi Jamaat's reception to Hadith on COVID-19', DINIKA: Academic Journal of Islamic Studies 5(2), 191-212.

Qudsy, S.Z., Masduki, M. \& Abror, I., 2017, 'Puasa Senin Kamis di Kampung Pekaten', in Annual conference for Muslim scholars Kopertais Wilayah IV Surabaya, pp. 564-573, viewed 15 October 2020, from proceedings.kopertais4.or.id/index. php/ancoms/article/view/103
Rajab, K., 2010, 'Psikologi Iman sebagai Penguatan Nilai Teologis dalam Kesehatan Mental Islam', Sosio-Religia 9(3), 919-932.

Salehudin, A., 2018, 'Theologizing farming: Religiosity and economic rationality of Muslim people in the Dieng mountains', Dissertation, Gadjah Mada University, Indonesia.

Setiawan, W.L., 2020, 'Program one Pesantren one product Dapat Menjadi Pendekatan Akselerasi Bisnis Di Pesantren Pada Masa Pandemi COVID-19', Jurnal Pengabdian Kepada Masyarakat I(2), 55-60.

Setiawan, A.E., Rizki, F., 2020, 'E-Learning Sebagai Pembelajaran Inovatif Pada Masa Pandemic Covid-19 Di Pondok Pesantren Darul Huffaz', Jurnal Pengabdian Kepada Masyarakat Ungu 2(2), 100-103.

Smart, N., 2000, World views: Cross cultural exploration of human belief, Prentice Hall, Hoboken.

Shufiyah, F., 2018, 'Pernikahan Dini Menurut Hadis dan Dampaknya', Jurnal Living Hadis 3(1), 47-70. https://doi.org/10.14421/livinghadis.2017.1362

Suryadi, S. \& Mansur, M., 2017, 'Peran Kajian Islam Berbasis Pesantren Tradi sional sebagai Pemblokir Aliran Radikalisme dan Intoleransi', ESENSIA: Jurnal IImu-IImu Ushuluddin 18(2), 225-239. https://doi.org/10.14421/esensia.v18i2.1483

Syahid, A., 2020, 'Living hadith in the practice of distancing the line (șaff) in congregational prayers during corona pandemic', Jurnal Living Hadis 5(2), 245-266. https://doi.org/10.14421/livinghadis.2020.2284

Tolchah, M. \& Mu'ammar, M.A., 2019, 'Islamic education in the globalization era: Challenges, opportunities, and contribution of Islamic education in Indonesia' Humanities and Social Sciences Reviews 7(4), 1031-1037. https://doi. org $/ 10.18510 / \mathrm{hssr} .2019 .74141$

Tucker, M.E., \& Grim, J., 2003, 'Introduction', in R.C. Foltz, F.M. Denny, \& A. Baharuddin (eds), Islam and ecology: A bestowed trust, Center for the Study of World Religions, Cambridge.

Vermeer, P. \& Kregting, J., 2020, 'Religion and the transmission of COVID-19 in the Netherlands', Religions 11(8), 393. https://doi.org/10.3390/rel11080393

Wahid, A., 2000, Prisma Pemikiran Gus Dur, LKiS, Yogyakarta.

Wahid, A., 2001, 'Pesantren sebagai Sebuah Subkultur', Menggerakkan Tradisi: EsaiEsai Pesantren, LKiS, Yogyakarta.

Wasyik, T. \& Hamid, A., 2020, 'Implementasi e-learning dalam Pembelajaran Alquran era COVID-19 di Sanggar Tahfidz entrepreneur Krian Sidoarjo', EDUDEENA: Journa of Islamic Religious Education 4(1), 13-24.

Wujtewicz, M., Dylczyk-Sommer, A., Aszkiełowicz, A., Zdanowski, S., Piwowarczyk, S. \& Owczuk, R., 2020, 'COVID-19 - What should anaesthesiologists and intensivists know about it?', Anaesthesiology Intensive Therapy 52(1), 34-41. https://doi. org/10.5114/ait.2020.93756

Yaqub, S., Rana, M.U. \& Aukrust, P., 2020, 'Ramadan under COVID-19-pandemien', Tidsskrift for Den Norske Laegeforening: Tidsskrift for Praktisk Medicin, Ny Raekke, viewed 20 October 2020, from https://doi.org/10.4045/tidsskr.20.0390

\section{Online sources}

https://news.detik.com/berita-jawa-barat/d-5251611/klaster-pesantren-rumahtangga-picu-kasus-Covid-19-jabar-lampaui-jakarta/2.

https://tirto.id/kemenag-27-pesantren-jadi-klaster-corona-1400-santri-positif-f5q2.

https://www.ayotegal.com/read/2020/11/15/5330/32-pondok-pesantren-diindonesia-jadi-klaster-Covid-19.

https://www.suaramerdeka.com/regional/semarang/246643-lebih-100-kyaimeninggal-akibat-Covid-19.

https://journal.ummat.ac.id/index.php/pendekar/article/view/2827.

https://www.cnnindonesia.com/teknologi/20201015075933-199-558577/hasilsurvei-ahli-soal-konspirasi-corona-dan-keraguan-vaksin.

https://bisnis.tempo.co/read/1318951/kominfo-ada-196-hoaks-virus-coronaterbanyak-di-fb-dan-twitter.

https://www.liputan6.com/regional/read/4221072/kronologi-transmisi-lokal-dalamkasus-positif-corona-Covid-19-di-yogyakarta. 